\title{
Uncertainty and Educational Mismatch
}

\section{Schooling and Life Pursuits in Contexts of Illegalization}

\author{
Susan Bibler Coutin
}

This chapter draws on the literature on liminality, uncertainty, and precarity to analyze the complicated mismatches between the lives of immigrants and the forms of deservingness produced through US immigration enforcement initiatives. Since passage of the Illegal Immigration Reform and Immigrant Responsibility Act (IIRIRA) in 1996, the mechanisms through which undocumented noncitizens could regularize their status in the United States have been highly restricted. ${ }^{1}$ Access to asylum has been increasingly curtailed, presence bars have made it hard for noncitizens to qualify for family visa petitions, and hyper-criminalization, overpolicing, and stiffened border enforcement have created records that disqualify many from consideration. ${ }^{2}$ Avenues for relief have increasingly taken highly liminal forms, such as Temporary Protected Status (TPS) or Deferred Action for Childhood Arrivals (DACA), which have to be renewed at regular intervals, confer only limited rights (such as work authorization and relief from deportation), and are vulnerable to being overturned, as the Trump administration attempted to do. ${ }^{3}$ In such an atmosphere of heightened enforcement and limited opportunity, "deservingness" has been defined in a constrained fashion that privileges sacrifice, achievement, personal responsibility, and law abidingness. This limited definition defines "deservingness" as an individual character trait, ignoring the structural conditions that shape whether or not individuals are able to do things like excel in school, graduate, work, advance in careers, and avoid behaviors that could lead to accusations of

1 N. Morawetz, "Understanding the Impact of the 1996 Deportation Laws and the Limited Scope of Proposed Reforms" (2000) 113(8) Harvard Law Review 1936-1962.

2 J. M. Chacón, "Overcriminalizing Immigration" (2012) 102(3) Journal of Criminal Law and Criminology 613-652; R. Gomberg-Muñoz, "The Juárez Wives Club: Gendered Citizenship and US Immigration Law" (2016) 43(2) American Ethnologist 339-352.

3 C. Menjívar, "Liminal Legality: Salvadoran and Guatemalan Immigrants' Lives in the United States" (2006) 111(4) American Journal of Sociology 999-1037; S. B. Coutin et al., "Deferred Action and the Discretionary State: Migration, Precarity and Resistance" (2017) 21(8) Citizenship Studies 951-968. 
criminality. The very circumstance of being undocumented may compel individuals to use false Social Security numbers, work without authorization, drive without licenses, and reenter the country to join family members. ${ }^{4}$ Immigration law thus makes otherwise legitimate activities - working, studying, traveling, being with family - appear as markers of undeservingness. Legal definitions of "deservingness" are therefore misaligned with the realities of living in the United States without authorization.

Aligning definitions of deservingness with the realities of immigrants' lives is key to ensuring respect for human rights. The most inclusive basis for granting people rights in international law is humanity. ${ }^{5}$ Basic human rights, such as the right to life, liberty, equality, and freedom from persecution are to be enjoyed by "all members of the human family." Such ideals inspired the immigrant rights' slogan "no human being is illegal."7 In contrast to such notions of universality, political membership has been seen as a basis for limiting rights. Drawing on the theory that there is a social contract between citizens and state, ${ }^{8}$ notions of political membership limit specified political and civil rights to those who are party to this contract. Grounding rights in notions of political membership, rather than humanity, draws distinctions between those who are and are not members of a given society. Alongside theories of membership, however, are understandings of disadvantage, according to which certain vulnerable groups are considered deserving of rights regardless of their formal citizenship status. Such groups include women, children, refugees, workers, the indigenous, and racial and ethnic minorities. ${ }^{9}$ These groups are thought to have unique needs that cannot be adequately captured in universal declarations.

The gaps between universal human rights, bounded political membership, and particular disadvantage make educational pursuits particularly fraught for undocumented students, as individualized notions of deservingness collide with the forms of exclusion to which they and their families are subjected. In the United States, the Supreme Court decision in Plyler v. Doe established that public education cannot be denied to K-12 students on the basis of immigration status. ${ }^{10}$ As a result, schooling

4 H. Lewis and L. Waite, "Asylum, Immigration Restrictions and Exploitation: Hyper-precarity as a Lens for Understanding and Tackling Forced Labour" (2015) 5 Anti-Trafficking Review 49-67.

5 Y. N. Soysal, Limits of Citizenship: Migrants and Postnational Membership in Europe (Chicago: University of Chicago Press, 1994).

6 Universal Declaration of Human Rights, December 10, 1948, United Nations General Assembly Res. 217A(III), pmbl.

7 M. M. Ngai, “No Human Being Is Illegal” (2006) 34(3/4) Women's Studies Quarterly 291-295.

8 J. F. Collier, B. Maurer, and L. Suarez-Navaz, "Sanctioned Identities: Legal Constructions of Modern Personhood" (1995) 2(1-2) Identities 1-27.

9 D. Reynaert, M. Bouverne-de-Bie, and S. Vandevelde "A Review of Children's Rights Literature since the Adoption of the United Nations Convention on the Rights of the Child" (2009) 16(4) Childhood 518-534; P. Thornberry, "Confronting Racial Discrimination: A CERD Perspective" (2005) 5(2) Human Rights Law Review 239-269.

10 Plyler v. Doe, 457 U.S. 202 (1982); L. J. Abrego and R.G. Gonzales, (2010) "Blocked Paths, Uncertain Futures: The Postsecondary Education and Labor Market Prospects of 
is something of a protected space and life stage in which the impacts of being undocumented, or of having undocumented relatives, are muted. ${ }^{11}$ Yet in other ways, schooling is one of the arenas where the contradiction between legal measures of deservingness and the structural conditions that limit opportunity play out. Children who are undocumented or who have relatives who are at risk of deportation experience anxiety, ${ }^{12}$ material deprivation, and restrictions on travel, all of which can influence their school experiences. ${ }^{13}$ Furthermore, as undocumented children reach adolescence, they "awaken to a nightmare"14 in which driver's licenses, identity documents, work authorization, and the financial resources needed to attend college are often beyond their reach. Some states, such as California, have attempted to ease these burdens, and DACA has helped, but DACA's future is highly uncertain, and state and local measures do not go far enough. Navigating schooling in a context of illegalization can therefore be like walking through a minefield.

To explore how this highly punitive environment shapes educational pursuits, this chapter draws on two sets of data: (1) interviews that the author conducted between 2006 and 2010 with 501.5 generation young adults, that is, immigrants who were born in El Salvador, immigrated to the United States as children, and were raised in Southern California, thus falling between the first generation (born outside of the country) and the second generation (born in the United States), and (2) interviews that the author and colleagues carried out between 2014 and 2017 with Latinx and Asian and Pacific Islander individuals who either had DACA or who had hoped to apply for deferred action under the Deferred Action for Parents of Americans program that the Obama administration announced in 2014 but that never went into effect. The 2006-2010 interviews with Salvadoran 1.5 generation youth in Southern California focused on interviewees' experiences of the Salvadoran civil war, journeys to the United States, childhoods in Southern California, family circumstances, identities, return trips to El Salvador if any, transitions to adulthood, legal histories, and future aspirations. Educational experiences were a key focus in these interviewees' discussions of their childhoods, current circumstances, and goals. Interview results therefore indicate how immigration law

Undocumented Latino Youth" (2010) 15(1-2) Journal of Education for Students Placed at Risk 144-157.

${ }^{11}$ R. G. Gonzales and L. R. Chavez "Awakening to a Nightmare': 'Abjectivity and Illegality in the Lives of Undocumented 1.5-Generation Latino Immigrants in the United States" (2012) 3 Current Anthropology: A World Journal of the Sciences of Man 255-281.

12 J. Dreby, "The Burden of Deportation on Children in Mexican Immigrant Families" (2012) 74 (4) Journal of Marriage and Family 829-845.

${ }^{13}$ H. Castañeda, Borders of Belonging: Struggle and Solidarity in Mixed-Status Immigrant Families (Stanford, CA: Stanford University Press, 2019); C. Getrich, Border Brokers: Children of Mexican Immigrants Navigating US Society, Laws, and Politics (Tucson: University of Arizona Press, 2019).

${ }^{14}$ Gonzales and Chavez, "Awakening to a Nightmare." 
shaped schooling in the period before DACA. The interviews that were carried out in 2014-2017 in the post-DACA era also included accounts of schooling and of educational goals, particularly in the case of interviewees who had or hoped to qualify for DACA. Pseudonyms have been used for all interviewees. Together, this interview material reveals the ways that racialization, illegalization, and precarization shape educational opportunities, even in a state that welcomes immigrants, such that the educational achievements that might be considered hallmarks of deservingness are placed beyond the reach of many, regardless of their individual talents or abilities. This material also reveals the resourceful strategies through which interviewees, their families, and some educators pushed back against these forces to attain educational goals.

Theory regarding illegalization, precarity, and uncertainty suggests that defining deservingness as an aspect of individual identity ignores the structural forces that shape individuals' lives. Scholars have examined illegalization in order to emphasize that individuals, families, and communities are not intrinsically "illegal" and therefore "undeserving"; rather, they are constituted as such by state and other actors as an ongoing part of daily life. ${ }^{15}$ Furthermore, the illegalization literature suggests there is not a dichotomy between being undocumented and having status, as there are gradations of partial and temporary statuses. ${ }^{16}$ This sort of differentiation in status has implications for educational opportunities, as it influences travel, financial resources, mental health, material conditions, and ability to plan. Likewise, educational institutions can play a role in furthering or mitigating this process. Illegalization is closely connected to precarity, which has been defined as "that politically induced condition in which certain populations suffer from failing social and economic networks of support and become differentially exposed to injury, violence, and death." ${ }^{\prime 7}$ Immigration status contributes to precarity by limiting access to employment, healthcare, family, safety, and more. The condition of precarity extends across multiple contexts, thus creating commonalities between noncitizens

15 C. Dauvergne, "Making People Illegal," in M. Crock (ed.), Migrants and Rights (New York: Routledge, 2017), pp. 74-94; L. F. Plascencia, "The 'Undocumented' Mexican Migrant Question: Re-Examining the Framing of Law and Illegalization in the United States," 38(2) Urban Anthropology and Studies of Cultural Systems and World Economic Development 375-434; L. Schuster, “Turning Refugees into 'Illegal Migrants': Afghan Asylum Seekers in Europe" (2011) 34(8) Ethnic and Racial Studies 1392-1407; P. E. Villegas, "Assembling a Visa Requirement against the Mexican 'Wave': Migrant Illegalization, Policy and Affective 'Crises' in Canada" (2013) 36(12) Ethnic and Racial Studies 2200-2219; P. E. Villegas "Fishing for Precarious Status Migrants: Surveillant Assemblages of Migrant Illegalization in Toronto Canada" (2015) 42(2) Journal of Law and Society 230-252.

16 S. Chauvin and B. Garcés-Mascareñas, "Becoming Less Illegal: Deservingness Frames and Undocumented Migrant Incorporation (2014) 8(4) Sociology Compass 422-432; M. Reeves, "Clean Fake: Authenticating Documents and Persons in Migrant Moscow" (2013) 40(3) American Ethnologist 508-524.

${ }^{17}$ J. Butler, "Performativity, Precarity and Sexual Politics" (2009) 4(3) AIBR. Revista de Antropología Iberoamericana at ii. 
and other marginalized and racialized groups. ${ }^{18}$ Precarity impacts access to education, as well as the material conditions within which schooling occurs, making it difficult for youth to be the "high achievers" that are lauded in narratives about "DREAMers" who are cheerleaders or high school valedictorians but are also undocumented. Lastly, uncertainty is a key facet of both illegalization and precarity, given that immigration law and policy change over time, temporary statuses are vulnerable to political exigencies, and pathways to regularization may be blocked or shrouded. ${ }^{19}$ Uncertainty makes it hard for noncitizens to plan for the future, understand the rules to which they are subject, and know whether adverse records about them have been created. Planning and record-keeping are key to educational pursuits, so again, schooling can be impacted by and in turn shape individuals' experiences of uncertainty in ways that make educational achievement difficult to demonstrate.

\section{EDUCATION AND ILLEGALIZATION PRE-DACA}

Interviews conducted between 2006 and 2010 with 1.5 generation Salvadoran immigrants in Southern California shed light on the relationships between illegalization, precarity, uncertainty, and education during the period before the DACA program recognized graduation from US high schools as a marker of deservingness. While a few of these interviewees reported being impacted due to immigration status, for the most part it was illegalization and precarization more generally that affected their school experiences, rather than legal status in particular. Illegalization impacted their parents' employment opportunities, which in turn led their families to live in neighborhoods characterized by poverty, racial tensions, crime, and pressures to join gangs. In this context, instead of being places of safety, schools became one place where children experienced violence and discrimination. Moreover, all too often, interviewees reported school officials and policies that exacerbated educational disadvantage by, for example, treating language skills as a measure of academic ability or requiring students to complete grade levels that they had already completed in their country of origin. Sometimes, however, school programs, counselors, or teachers intervened to mitigate illegalization, precarization, and educational disadvantage, such as by enrolling children in gifted classes, helping them graduate, or steering them toward college. Children and their families also resisted disadvantage through self-advocacy and developing support networks. The transition to college or the workplace was nonetheless challenging to these young people. In

18 L. Goldring and M.-P. Joly, "Immigration, Citizenship and Racialization at Work: Unpacking Employment Precarity in Southwestern Ontario (2014) 22 Just Labour 94-121.

19 M. B. E. Griffiths, "Out of Time: The Temporal Uncertainties of Refused Asylum Seekers and Immigration Detainees" (2014) 40(12) Journal of Ethnic and Migration Studies 1991-2009; I. Hasselberg, Enduring Uncertainty: Deportation, Punishment and Everyday Life (New York: Berghahn Books, 2016). 
California, Assembly Bill 540 gave undocumented high school graduates the right to pay in-state tuition, ${ }^{20}$ but the inability to qualify for federal financial aid or work legally placed college and therefore educational achievements out of reach for many. For those who managed to attend college anyway, universities provided the opportunity to organize new programs to overcome educational disadvantage.

Interview material suggested that, even though undocumented and immigrant children had the legal right to attend public schools, these institutions were not isolated from the broader social pressures that impacted children's families and neighborhoods. Interviews were replete with references to poverty, gangs, and violence. Adelmo Ariel Umanzor, whose family fled El Salvador during the civil war, observed, "If you were Salvadorian you were [presumed to be] like straight-MS. You know and nobody liked MS or - That kind of created a lot of like conflict... between students you know. Because that's why I didn't go to Belmont High School. I went to Pacific Palisades. Because in Belmont High School, gee, they were like all kinds of gangs in there." Jessica Morales explained how attending a middle school in a low-income neighborhood impacted her:

That [going to Virgil Middle School] was probably the worst experience I've had in any of my schooling .... For some time I felt like somewhat ashamed of being Latino. I really did, because the kids were just trouble-makers. They were tagging. They were, you know, in gangs. And here I am as goody-two-shoes and I have to adapt to that very quickly. So, in 6th grade I didn't really have too many friends. I really didn't. There was a lot of girls that didn't like me and loved to pick on me because I was ... an easy target. By 7 th grade, similar to my brother, I got tired of being a target, so then I started getting into trouble. I started dressing more like them.

Note the way that Jessica equated "trouble-making" with race and ethnicity, while Adelmo commented that merely being Salvadoran gave him a presumed gang affiliation. In fact, racial and ethnic tensions were pervasive in the public schools attended by interviewees. Marta Dominguez reported that her school actually experienced riots: "I was teased a lot by Mexicans .... Within Latinos we are so diverse that Mexicans kids were always being like 'Oh you Salvi' and you know, this and that. So there was a lot, like, so much more riots at school because of that." Thus racialization impacted students' school experiences in ways that made it difficult for them to excel.

Instead of being neutral institutions, school policies and personnel in some ways contributed to these tensions and forms of marginalization. Salvadoran children who were viewed as troublemakers, for example, were suspended or otherwise disciplined, thus making them appear undeserving, often for reasons beyond their

${ }^{2 \circ}$ L. Abrego, "Legitimacy, Social Identity, and the Mobilization of Law: The Effects of Assembly Bill 540 on Undocumented Students in California" (2008) 33(3) Law \& Social Inquiry 709-734. 
control. Cesar Quintanilla, the United States-born son of Salvadoran parents, reported that he was deeply distrusted by his English teacher:

I was bleeding, because I used to get bloody noses all the time. And I used to be bleeding. And then like, I'm already there holding my nose, and I was like, "Mr. [name deleted], I'm bleeding. I need to go to the bathroom." And he's like, "Cesar, stop it." And I'm here bleeding, and holding my nose, and I'm like, "Mr. [name deleted], I'm bleeding, look, there's blood." And he's like, "Cesar, stop it!" And I just couldn't take it. I just left! I just went to the bathroom. I think I got in trouble for that. And it was just funny how he thought I was lying, with blood on my hands, you know?

Another common practice, according to interviewees, was placing children in grades that they had already completed, thus making them stay in school more years than necessary. Marta Dominguez, who eventually became a staff person at a fouryear college, recalled:

Math, that's all they gave me. No other thing because, I guess, because I couldn't speak the language. And, then they would, I thought it was kind of weird because I wasn't, they put me back in third grade when I came. So it was kind of upsetting because I wanted to go to fourth grade. And, uhm, they gave me a lot of like easy stuff. Like, uhm, multiplication and divisions with just one digit. And, I was already doing fractions in El Salvador.

Numerous interviewees felt that they were evaluated on the basis of their language skills or immigrant status instead of their academic qualifications. Ernesto Duran complained that he was inexplicably held back for a year in elementary school, Bayardo Morazan stated that a high school counselor wanted to put him in remedial classes rather than honors due to his accent, and Sandra Mejillas went from testing into a gifted program at one school to being placed in English-as-a-second language (ESL) classes in another. Several interviewees reported that even though they eventually performed well at four-year institutions, their high school counselors had steered them toward community college or military enlistment. They saw such "guidance" as racially biased.

In the worst-case scenario, illegalization, precarization, and school policies that disadvantaged Salvadoran children resulted in dropping out of school, an outcome that contrasted with the DREAMer narrative of high-achieving immigrant youth. Manuel Cañas had this experience. During the second semester of gth grade, Manuel's mother was working the night shift and needed Manuel to watch his siblings during the day so that she could sleep. He tried to go to night school to complete his high school degree, but felt the pressure to earn money. So, he accepted a gth grade diploma and in addition to caring for his siblings and cousins, he did piece work at a factory, worked in a restaurant, and, at the time of our interview, had become a baggage handler at the airport, a job he was able to get due to having work authorization as a TPS recipient. Definitions of deservingness that 
emphasized educational achievement were misaligned with the pressures of Manuel's life.

While schools frequently contributed to or failed to protect Salvadoran children from marginalization, there were instances when schools, programs, teachers, or counselors supported interviewees in ways that mitigated the impacts of precarization and illegalization. Some students attended schools that had more resources. Juana Rocio related, "I think it was an advantage coming at such an early age, 3 years old ... I was like Sponge Bobs, sponging everything that I learned," while Verónica Reina recalled happily that her parents gave her "the perfect childhood experience." As a recent arrival, Marta Dominguez perceived her school as a place of abundance: "l loved the school because it had like, all these wonderful things. And, toys, and letters like, really cute decorated. I was, like, I was amazed with the school. And, then the fact that they fed us [laughs]. That was just like, new to me." Some interviewees singled out a teacher who had made a difference in their lives. Mónica Ramirez spoke of a teacher who "saw me like a daughter and I still remember her," while Adelmo Ariel Umanzor appreciated teachers who noticed that he was from El Salvador and gave him books about the Salvadoran Civil War. Saul Henriquez recognized a counselor who believed in him. She told him, "you're doing B- work. This is not you. You can do this [other] type of work." Interviewees also described teachers who fought for them, getting them transferred into honors classes or college-bound programs. Cesar, who had been mistrusted by his English teacher, attributed his success in college at least partially to a mentorship program. As a fourteen- or fifteen-year-old, Cesar's mentor would "take me to places, to events, to college trips. He would just take me anywhere, anywhere he would take me, I used to love it, because it was a place that I wouldn't go if I would not have met him. So to the museum, to the opera, to the orchestra." Such individuals and programs helped to counter educational disadvantage wrought by poverty. But interviewees seemed to see them as exceptions, "rare to find a teacher like that," as Mónica Ramirez put it.

Interviewees also resisted educational marginalization, primarily through workarounds, self-advocacy, family and peer support networks, and "passing." Jessica Morales was slated to attend an inner-city high school where her older brother had gotten into trouble. Jessica persuaded her parents to use someone else's address so that she could enroll in a middle-class high school in the San Fernando Valley. Graciela Nuñez successfully fought to be transferred to honors classes. She related:

And then I got to high school .... I remember I had integrated science and I was really mad because I really wanted Biology and then Chemistry, and Physics - the sciences separate. And I told the counselor and then the counselor was like, "No we can't do that." And then I talked to like the head counselor and then she said, "No, we can't pull you out for some reason." And then she said, "If you do really well, we could put you in Physics next year." So then I did really well that year and that's how I got to go into the Honors Program at the school. 
Peers and family were also sources of support. Araceli Muñoz's grandmother sent a grammar book from El Salvador so that Araceli would not forget Spanish, Manuel Cañas made friends who helped him acclimate to elementary school, and Walter Olivar's friends encouraged him to make his first public speech in English, despite having an accent: "Come on you can do it. Walter, you can do it. Come on go, you can do it." Lastly, some interviewees reported that they "passed" as Mexicans, to avoid being stigmatized as Salvadorans, and as citizens, to avoid being accused of illegality. Marta Dominguez said, "There was a lot of, like, Salvadorans, when I was growing up, because of that tension that there was in school, the majority were Mexican, they would deny who they were so they wouldn't get, like, beat up. Or picked on. Yeah, it was sad because we had to, like, pretend to be Mexican." Likewise, Jessica Morales recalled being ashamed to be a permanent resident rather than a citizen. She stated, "I remember when I was in junior high I think somebody was talking about being a citizen and they said, 'Oh, but you were born here right? You're a citizen?' And I lied and I said, 'Yes."' These forms of resistance - workarounds, self-advocacy, social support networks, and passing - helped individuals navigate public schools in ways that made them appear deserving, but did not actually change oppressive structures that produced education disadvantage.

Unlike K-12 education, where legal status did not pose a barrier to enrollment, transitioning to college was significantly impacted by legal status, as has been well documented. ${ }^{21}$ In 2001, California approved Assembly Bill 540 (AB-540), which allowed undocumented high school graduates to pay in-state tuition at public colleges and universities, ${ }^{22}$ so during the 2006-2010 period in which these interviews were conducted, interviewees were eligible for this more affordable tuition rate. Nonetheless, lack of work authorization, the inability to drive legally, and ineligibility for financial aid placed college beyond the reach of many. Beatriz Gonzalez, an activist in the California Dream Network, described her own experience:

And so, end of junior year, I wanted to go to college, I got to visit [UC] Davis. So I remember feeling, "No! I can't just not go to college. That's not an option. And I don't want to go to a community college" because I had like a 4.1 GPA, and was like, "No, I want to go to UC."

So AB-540 became law, and I applied for every possible scholarship that I could get ahold of. At the end of my senior year, I had fundraised \$500. And so, during that time, UC Davis, the quarter system, so it's three quarters and it was $\$ 1450$ per quarter. So it was like, I did the math and "well, I have enough money for my tuition." And so I talked to my parents, and I said, "You know, can you guys help me pay for my rent?" And they said, "if it's something around \$250. No more than \$300 a month, then we can help you. If not, then you should really consider staying here." And I said, "No, no. I'll find out."

${ }^{21}$ Gonzalez and Chavez, "Awakening to a Nightmare."

${ }^{22}$ Abrego and Gonzales, "Blocked Paths, Uncertain Futures." 
And so it worked. I went up there and did some homework and found a place to share for that amount. Got in the newspaper and found a job as a caregiver for a quadriplegic woman. And so that's how I was able to start in Davis. Because I knew I had enough money for my tuition.

And so I went there all my four years, and I, every year, was that same pressure. So again, it's like, I guess too the common thread or theme is that to be undocumented means to have to walk the unconventional path. And so, so you know, while I remember everybody feeling like, "Yes! Finals are over!" And like, "let's relax!" I remember thinking, "Yes! Finals are over! Oh, gosh" you know, "I gotta keep on searching, I gotta keep on asking, "where can I get money?"

While Beatriz succeeded in graduating from UC Davis, her college experience was shaped by continual worry about financial resources. Deservingness, in her case, was not an individual attribute but a product of circumstances. Such worries were shared by other interviewees who were frustrated by lack of immigration reform. As a TPS holder who had employment authorization, Tomás Marino-Vargas was working his way through college. But delays in government renewals of TPS put his job at risk. Although he was able to get a sticker showing that the US government had extended his expired Employment Authorization Document (EAD), Tomás' employer doubted the validity of this document. Only when the new EAD, valid for eighteen months, arrived, was his employer satisfied. Meanwhile, these difficulties had caused Tomás to withdraw from school. Consumed by uncertainty, Tomás related:

I've put my life, like, on hold, you know, to getting married and all that because I don't want to have that whole double issue of dealing with that until I get at least myself - my affairs straightened out .... School, um - I kinda felt - I felt cheated by the system because so many people get money, you know, to go to school and - and um, for their expenses, that when it came to me, it's like, hey, you know, I'm trying to do the same, but because I'm not here legally, I guess you could say, um, I have no rights to that.

One way that students fought against uncertainty was by organizing for policy change so that definitions of deservingness would better align with their lives. Schools were a place that afforded students the opportunity to form clubs and organizations, launch campaigns to pass the federal Dream Act, which would have created a pathway to legal status and eventually citizenship for undocumented students. As well, at the state level, students successfully fought for passage of the California Dream Act, which gave them access to state financial aid. In high schools, students formed AB-540 clubs, where they came together with other students who were also undocumented. Marisol Sanabria explained how she organized one such club at her high school, and then continued her activism in college. After revealing her undocumented status to a teacher to explain why she could not participate in a field trip to Washington, DC, he told her: 
“Tomorrow we're going to have meeting and you're going to start a club, you know. Not only for immigrants, but for everybody. And you're going to fundraise to have scholarship for you - for you guys, you know." And that's how I became open. And I started going to places, talking to people. And ... now in college we have come to my high school from Cal Poly Pomona trying to make people apply to our school. And then I'm there just talking to people like - and we have a section for AB-540, and we tell them, "You know what, you're not alone .... The government can't help you financially, but there are people like out there [who can], you know."

Students also used college campuses as a platform for organizing. At California State University, Los Angeles, several Salvadoran students formed a student club known as USEU, the Unión Salvadoreña de Estudiantes Universitarios, or the Salvadoran University Student Union. USEU members sought to counter popular images of Salvadorans as gang members by highlighting their own status as university students. In addition, they worked with local high schools to educate undocumented and other students about opportunities to attend college. Cesar Quintanilla, who helped found this group, explained, "What we're trying to do with this organization, we're trying to show, like, we're trying to go out to the community and go out to the high schools, and not just our Salvadoran youth, we're going to focus on them, but not just them, just show our history, why we're here. Nobody tells us that." Salvadoran youth also promoted social change through their own research, scholarship, and creative work. Through organizing, activism, and becoming scholars in their own right, students helped to lay the groundwork for DACA.

\section{ILLEGALIZATION, PRECARIZATION, AND UNCERTAINTY POST-DACA}

Interviews conducted between 2014 and 2017 with individuals who had or hoped to apply for deferred action suggest that the combination of DACA and state and local integrative policies helped to mitigate but did not entirely overcome the impacts of illegalization and precarity. Students had more opportunities for academic success in the post-DACA era, but again, structural conditions shaped their lives in ways that deviated from narratives that treated educational achievement as an individual attribute. Unlike the 2006-2010 interviews with 1.5 and second-generation Salvadoran youth whose families immigrated to the United States during the Salvadoran Civil War, the 2014-2017 interviews were conducted with members of two generations: those who potentially could have applied for deferred action through DAPA, had it gone into effect, and college-age students who had DACA or potentially could have applied. The former group tended to be over thirty-five (many were parents), and the latter group tended to be in their twenties. Moreover, the 2014-2017 interview participants were from a range of countries, most commonly Mexico, but also Peru, Central America, Korea, Ethiopia, and China. Although the younger generation of 2014-2017 interviewees had entered the US educational system later than the 2006-2010 interviewees, there were striking similarities in their 
experiences. Many faced challenges acclimating to US schools when they were young and many also went through the traumatic adolescent experience of discovering that they were undocumented and therefore faced curtailed educational opportunities. For some, DACA and California state policies provided the means of pursuing college, often at high personal sacrifice, but the illegalization and precarization to which their families were subjected still created financial challenges. Educational institutions therefore helped to mitigate but could not overcome the impacts of illegalization. In the best-case scenario, schools, colleges, and universities were places of advocacy and empowerment, but in the worst-case scenario, educational institutions denied opportunities, thus exacerbating illegalization and precarization. Moreover, continued uncertainty over DACA, the intensification of enforcement, and an increase in overt xenophobia and racism made many interviewees anxious about their future prospects.

The early school experiences of the post-DACA interview group were not unlike those of pre-DACA interviewees. Mireya, a college student in her twenties at the time of our interview, was one of the few who described being directly impacted by immigration law as young children. Mireya had wanted to learn the violin, but her mother, who was undocumented, was unwilling to sign the form for her to check out an instrument. Mireya lamented, "I've always thought that, had I been given the opportunity to do that [learn violin], I would have been a composer .... So that educational goal went flying away." Many interviewees reported that their initial school experiences were traumatic, not because of legal status specifically, but rather due to language and cultural differences. Imelda described school as "a struggle," recalling, "I was very shy because I didn't know anybody or anyone and ... I started off in kindergarten so most of the kids already knew the language." Marisol, a housecleaner who was in her forties, recounted that when her four-year-old son entered the US school system, he was so traumatized that he began vomiting and she had to pick him up from school: "He says, 'Mommy, they don't talk like me in the bus and the teacher kept asking me questions and I didn't know what she was saying,' so I started crying with him and I just said what did I do but I told him you can do it, you are going to learn English and you will be able to speak it. He then sat down and okay mommy." Despite such early challenges, interviewees expressed pride in their educational achievements. Joaquin had been frightened during kindergarten, but, he said, "after kindergarten, I went to bilingual classes, by and grade, I had entered into honors already. I made great progress." Some post-DACA interviewees also reported that the intervention of supportive teachers or counselors made a difference in their educational trajectories. Stephanie, whose family immigrated to the United States from South Korea, commented, "my fourth grade teacher was very patient with me. She sat one on one with me, she helped me learn how to write, and then pronounce. Like I think one of the reason I got better was because of her. She was remarkable." 
College-age post-DACA interviewees reported that it was during their teenage years that the reality of being undocumented hit them in ways that impacted them academically. Some, such as Mireya, were already aware of their immigration status. Others only learned that they were undocumented when they tried to apply for college, obtain financial aid, or qualify for driver's licenses. These interviewees found that any protections that they had experienced during K-12 schooling evaporated. Catalina, for example, told us "I didn't really know I was undocumented until I was like 14 or 15, and then I - my junior year, no my whole entire high school career, I was like how am I going to pay for college? Like that's not even possible." Bryce, who had immigrated to the United States from Thailand, discovered his undocumented status when he applied for his first job: "I tried to get a part-time [job] being a lifeguard. I got my certification and went out to apply and I eventually got turned down and they told me I couldn't work because my paperwork was kind of messed-up. I didn't have a social, like that worked properly and after that I kind of like, 'What?" Bryce described the moment when his parents explained his status as "surreal." Teenage years were a life stage when some were under pressure to join gangs, drop out of school in order to work, or assume family responsibilities. Imelda, quoted earlier, recalled of her own high school, "not a lot of kids would graduate." Added concerns about immigration status made such pressures more acute. Their teenage years were also a time when the impact of legal differences between themselves and their siblings became apparent. Older siblings, who had reached college age before DACA, had experienced greater educational disadvantage, whereas younger siblings who may have been United States citizens, were able to pay instate tuition and qualify for financial aid. Some interviewees felt guilty about their own opportunities, but also resentful about the disadvantages they faced.

Interviewees who qualified for DACA by attending or completing high school experienced some relief from educational disadvantages associated with immigration status. Bryce, who had feared that it would be impossible to complete college and attend medical school, stated, "with the [deferred] action itself like all of a sudden I have these rights that I never had before. I felt a lot more accepted and the community I was felt like my home. Yeah, when it came out I was just very thrilled about it .... When DACA came out that's when I really realized like hey, the future might not be as dark as I really anticipated .... All the hopes and goals I had suddenly became more plausible." California law also made a difference in expanding their educational opportunities. For example, Imelda, who had imagined that she would be restricted to community college and would have to take out many loans, related, "I always knew it would be tough for me to go to college .... I'm so thankful for the California Dream Act because that will help me so much .... Now I could go to UC." Similarly, Lupita, who was majoring in Public Health Policy with a minor in Civic and Community Engagement, said, "When I found out I could apply to AB 540 and the Dream Act and all that, I was like, 'Oh, cool." With in-state tuition and financial aid, for Lupita, education became affordable. 
Yet, despite DACA and California state policies, some interviewees still faced reduced opportunities. Not everyone qualified for DACA. Sonya, who was undocumented, completed a medical assistant degree but was turned away from an internship because she did not have a Social Security number. This experience was emotionally devastating. Choking up as she told the story, Sonya related, "I remember that I cried and cried. I walked for blocks and blocks without making my way towards home. I just wanted to clear my mind (desahogarme)." Even with financial assistance, college was still expensive. Nidia, for example, had to take a couple of semesters off to work so that she could help her family financially, while Alessandra, who had DACA, had to repeatedly take time off to work in order to pay for her education. She had been in college for eight years at the time of our interview. Some interviewees passed over opportunities to attend more prestigious universities for financial reasons. Joaquin, who was undocumented, recalled the educational challenges that he had faced:

It was hard to accept, year after year, not being able to transfer. You know, I was stuck at community college for seven years. And I didn't know if I was going to finish or make it. But I was starting to lose hope. And then along the way, I also had to sacrifice a lot of things .... I had actually dreamed with going to Berkeley. I got admitted every year that I applied .... In 2010 I tried to commit suicide, and I, I regret it, but I think it was a waking moment.

Finally, uncertainty about DACA's future coupled with the impacts of immigration enforcement created additional hardship for college students and their families. Catalina, who had DACA and was attending college at the time of our interview, worried,

I've always had a plan, right? I think that's something that I've always tried to do. But it's also been like this like kind of struggle with myself is that accepting that that probably won't be the case .... If I could have any kind of security in the future which is I think that something that I yearn for just because it's so much of my life has been unstable and going around it, trying to like going day by day, you know.

In the post-DACA era, educational institutions played complex roles in the lives of noncitizens who, in contrast to the notion of individual achievement celebrated in the DREAMer narrative, were subject to educational marginalization through illegalization, precarization, and legal uncertainty. On the one hand, institutions sometimes countered these processes, creating opportunities for inclusion, empowerment, and activism. Some high schools had special programs, such as Early Academic Outreach Program (EAOP) that enabled interviewees to prepare for college. Imelda, who went to high school in Compton, recalled that EAOP "helped me out with the college process and teaching me about the Dreamer [California Dream Act] and how to fill it out." Nidia's public school in Santa Ana provided educational materials in Spanish, which allowed her parents to participate in school activities. Catalina, who had never had health insurance, accessed health 
care through a student insurance program. Joaquin, who had taken ten years to complete his undergraduate degree, was able to envision pursuing a doctorate. Bryce learned how to apply for DACA through an educational organization, $\mathrm{E}_{4} \mathrm{FC}$ (Educators for Fair Consideration). Bryce then became active with an $\mathrm{E}_{4} \mathrm{FC}$ offshoot, Pre-Health Dreamers, which intervened with medical schools nationally to encourage them to admit undocumented students. Mireya obtained legal and financial assistance for the DACA process from her university, which also helped her siblings complete the DACA application. Dreamer Centers were particularly important sources of community for undocumented students. The parents we interviewed also stressed the ways that schools had enabled them to volunteer, attend workshops, and advocate for their children. Records of their volunteer activities also helped to document their time in the United States. Thus, the resources and programs that educational institutions provided allowed many interviewees not only to pursue their own educational goals, but also to become activists working for social, educational, and legal change.

On the other hand, though educational institutions were potentially empowering, schools, colleges, and universities also were in some ways that place where illegalization, precarization, and uncertainty occurred. Alessandra felt that she was discriminated against at school. She stated, "Because some of the schools, when it came to appointments, they ask you stuff like your social or you need to fill out an application and they ask you for a social and you have no social, like, they'll leave you just like that, you know, they won't even give you the appointment. I don't know, their tone of voice completely changes." Mauricio graduated from high school in Peru, and so did not qualify for AB-540. Because he had to pay nonresident tuition rates, he could not attend a university. Herminia did not qualify for DACA and had struggled to attend college, dropping out when she was only a few credits short of completing her degree. With exasperation, she commented, "I'm thirty-nine years old now, and I'm still trying to become, you know, legal. And yet I feel like my life has gone by and I haven't done much. And it's very frustrating because if I had had my residency when I was going to college, I would have finished and I would have a good job right now." Karina had DACA and was able to pursue her educational goals, but her father had been caught crossing the US-Mexico border and therefore would likely never be able to obtain legal status in the United States. Regardless of Karina's educational achievements, she was still potentially subject to being separated from her father through deportation. Some interviewees reported that their schools and universities were not well informed about DACA, AB-540, or the California Dream Act. They found themselves educating counselors, rather than vice versa. Some universities took insensitive actions, such as inviting the border patrol to campus to participate in a career fair or to speak in class. In that their admissions policies, record-keeping practices, advising procedures, and financial assistance was not always designed to accommodate the needs of undocumented students, educational institutions could be exclusionary, reproducing educational disadvantage, preventing social mobility, and exacerbating uncertainty. 


\section{DISCUSSION AND CONCLUSION: EDUCATIONAL MISMATCH}

The pre- and post-DACA interview material analyzed in this chapter demonstrates that definitions of deservingness that treat educational achievement as a measure of individual merit are out of sync with the ways that educational institutions further illegalization, precarization, and racialization. When schools deny access based on immigration status, charge higher tuition to noncitizens, or administer programs that require documentation that immigrant students lack, then schools are themselves perpetuating illegalization in ways that can prevent educational success. The precarization to which noncitizens are subjected also shape educational experiences. Impoverished communities also have under-resourced schools; poverty requires parents to work long hours, thus impacting their abilities to be involved in their children's schooling; and financial pressures may lead students to enter the workforce at young ages, or to care for siblings so that parents can work. Racialization and criminalization exacerbate these disadvantages, as schools treat students as potential gang members, or use discipline policies that alienate students. At the same time, this interview material also reveals that students, families, and educators have proven resourceful in pushing back against illegalization, precarization, and racialization. Interviewees described teachers and counselors who intervened positively in their lives, recognizing students' abilities, conveying information about college, and advocating for students within educational institutions. Families sometimes resorted to workarounds, such as using different addresses, to gain access of educational opportunities, while students engaged in self-advocacy in order to enroll in accelerated programs. In some cases, schools served as a platform for organization and empowerment, providing students with resources to apply for DACA, develop clubs and advocacy groups, build community, and forge alliances.

The complex roles that educational institutions play in relation to illegalization, precarization, and racialization are evidence that living in the United States without authorization undermines noncitizens' ability to demonstrate the "deservingness" that immigration policies often require. In other words, the undocumented are held accountable for the conditions that produce illegality, even though US policies create these conditions. For example, educational achievements are one way to show "deservingness," and in recent years, the DREAMer narrative has been celebrated, generating public sympathy for undocumented students. ${ }^{23}$ Yet, school systems are not always designed to support these students. Discipline practices may treat students of color as suspect, as described by Cesar, whose teacher did not allow him to go to the restroom even when he was bleeding. Schools sometimes treat language skills as a measure of academic achievement, placing non- or limitedEnglish speakers in remedial classes or lower-grade levels. College opportunities 
may be beyond the reach of some high school graduates, due to their immigration status or to the expense of college. A lack of educational achievement can be a product of the immigration system rather than a measure of noncitizens' own abilities. For these and related reasons, the DREAMer narrative has undergone considerable critique in recent years.

The similarities in interviewees' experiences pre- and post-DACA suggest that temporary measures, such as DACA, though valuable, are insufficient to counter both the intensity of illegalization, and the financial pressures of paying for college. The uncertain nature of DACA, which could potentially be dismantled through legal action or presidential policy, makes it difficult for students to plan. In fact, on June 18, 2020, in Department of Homeland Security v. Regents of the University of California, the US Supreme Court ruled that the Trump administration's rescission of the DACA program violated the Administrative Procedures Act (APA), due to being arbitrary and capricious. ${ }^{24}$ The DACA program has been allowed to remain in place, for the time being. Yet, a new rescission order that complies with the APA could be issued in the future, making the circumstances of DACA recipients precarious. Furthermore, even if DACA is allowed to remain in place, a new generation of undocumented students who did not immigrate to the U.S. before 2007 will be ineligible for DACA benefits. These students will face increased educational and other challenges. Even if state policies enable undocumented students to attend college, lack of work authorization could make it impossible for them to work professionally. Moreover, the high cost of college affects undocumented students, students with DACA, and low-income students. Creating campuses that are truly sanctuaries requires making college accessible to all who qualify, regardless of their immigration status or income. Continued advocacy for affordable education, the rights of undocumented students, and programs that more effectively integrate English language learners in the public schools is needed. Transformative advocacy could establish transnational educational partnerships, bridging boundaries within and beyond national borders, and placing students rather than politics and economics at the center of educational programming. In such a future, illegalization itself would be dismantled, not through legalization but rather by limiting the divisiveness of borders themselves in ways that allow all to enjoy the right to have rights.

24 Department of Homeland Security v. Regents of Univ. of Cal., 140 S. Ct. 1891 (2020). 